\title{
Meningococcal Syndrome in Albanian Children
}

\author{
Gjovalin Valca
}

Pediatrics Department, Rreshen Hospital, Albania

\begin{abstract}
Background: The universal epidemiology of persistent meningococcal disease (IMD) diverges distinctly by area and in due course. Neisseria meningitidis is one of the principal sources of bacterial meningitis worldwide and can as well cause sepsis, pneumonia, and further expressions. Methods: This appraisal summarizes the burden of IMD in diverse states and recognizes the highest-incidence countries where habitual preventive programs aligned with Neisseria meningitidis would be essentially profitable in offering security. Accessible epidemiological figures from the past 20 years in World Health Organization and European Centre for Disease Prevention and Control assortments and available articles are comprised in this review, in addition to straight statements with important specialists in the area. Results: The nations were clustered into high-, moderate-, and low-occurrence states. The mainstream of countries in the elevated-occurrence set are located in the African meningitis belt; several reasonable-occurrence states are located in the European and African areas, and Australia, whereas low-occurrence countries comprise numerous from Europe and the Americas. Precedence nations for vaccine involvement are high-and restrained-incidence nations where vaccine-avoidable serogroups prevail. Conclusions: Epidemiological records on burden of IMD are required in nations where this is not distinguished, predominantly in South-East Asia and Eastern Mediterranean areas, so evidence-based assessments concerning the application of meningococcal vaccines can be created.
\end{abstract}

Keywords: meningococcal illness, meningitis, epidemiology

\section{Background}

Neisseria meningitidis is one of the principal basis of bacterial meningitis worldwide and can furthermore cause sepsis, pneumonia, and further restricted diseases. There are 12 serogroups, but the mainstream of insidious meningococcal diseases are caused by individuals from the A, B, C, X, Y, or W-135 serogroups. The yearly quantity of insidious syndrome cases globally is approximated to be as a minimum 1.2 million, with 135,000 deaths linked to insidious meningococcal illness (IMD) $[1,2]$. In countries with elevated endemicity, the infection load puts an enormous harm on the public health scheme. The hazard of lasting hindering sequelae, comprising cognitive insufficiency, bilateral earshot loss, speed deficit, convulsions, image injury, hydrocephalus, and failure of limbs because of tissue necrosis, are uppermost in low profits countries, where the load of bacterial meningitis is supreme [3].

To fight IMD, many developed countries have comprised dissimilar formulations of meningococcal vaccine in their habit immunization agendas. A vaccine next to serogroup A has lately been established in the African meningitis belt, a region expanding from Senegal in the west to Ethiopia in the east [4,5]. Conversely, meningococcal vaccines remain underutilized internationally, mainly in source-restricted countries outside the African meningitis belt. To afford cost efficient proposals about the application of meningococcal vaccines, the country-detailed load of IMD must be recognized [6].

\section{Methods}

Our basis for the epidemiological statistics comprised the National Library of Medicine (PubMed), the World Health Organization (WHO) website of the Weekly Epidemiological evidence, and the European Centre for Disease Prevention and Control. We investigated PubMed with the subsequent key phrases: "Neisseria meningitidis" or "meningococcus".
The investigation was bounded to surveys of individuals, studies distributed in English, and dates of publication from 1995, to December 31, 2013. The primary investigation deferred 5320 outcomes from which surveys were rejected based on segregation criteria below. The data were acquired and comprised from WHO publications in the Weekly Epidemiological Record (WER) for the latest outlines from 10 African meningitis belt states.

From the exceeding literature exploration we prohibited general global approximation (excluding the identification of unique data suggestions), or surveys that were bounded to immunology, medicine resistance, or further nonepidemiological features. The WHO description of a meningococcal illness outbreak $(>100$ cases $/ 100,000$ inhabitants/year) relates exclusively to the meningitis belt. Supplementary countries infrequently skill epidemics with these elevated assault rates. We categorized countries regarding the level of endemic meningococcal illness as "elevated," "restrained," and "low" extension (Figure 1).

\section{Results}

Records on occurrence of meningococcal disease are presented underneath in Tables 1,2 and 3. Countries are clustered into precedence areas regarding the descriptions beyond, by means of general and available statistics from the previous 20 years. States not registered in the table have inadequate accessible IMD epidemiological figures to access correct taxonomy. Considerable gaps in data limit explanation of IMD epidemiology in some elements of the globe. In many nations with IMD inspection, widespread marked vaccine expansion and rising exposure has diminished the burden of syndrome.

The African Meningitis Belt, formerly distinguished by Lapeysonnie in 1963 [5] and adjusted in 1987, has the highest yearly occurrence of meningococcal illness in the world with cover up recurrent epidemics that comprise a chief public health load. Epidemics in the sub-Saharan area 


\section{International Journal of Science and Research (IJSR) \\ ISSN (Online): 2319-7064 \\ Index Copernicus Value (2013): 6.14 | Impact Factor (2014): 5.611}

overlap with the dry period, which has led to a supposition for the probable task of low dampness and seasonal dustwind carrying from the Sahara (the Harmattan) in harming the mucosa and producing painful coughing that helps diffusion $[34,43]$.

Twenty-five states in the African area with an enormously high prevalence of meningococcal infection comprise the meningitis belt. To quickly notice the recurrent epidemics, a tough surveillance coordination subsists that observes the amount of cases on an constant basis for quick reaction. This area has lately gained from a main coalition of global health bodies that have expanded and are organizing an reasonable and effective vaccine beside serogroup A meningococcus, which causes the mainstream of illness in this region, at population level [44].

Figure 1: A categorization of countries according to IMD attack rates

Table 1: Countries with high endemic rates ( $>10$ cases/100,000 population) and/or $>=1$ epidemic over the last 20 years

\begin{tabular}{|c|c|c|c|c|c|}
\hline Country & Year & $\begin{array}{c}\text { Incidence } / 100,000 \\
\text { population }\end{array}$ & \begin{tabular}{|c|} 
Predominant \\
Serogroup \\
\end{tabular} & Source & Comments \\
\hline African Region & 1994-2000 & & $*$ & & \\
\hline Angola & 1980-1999 & $19-230$ & & $(8)$ & \\
\hline Benin & 2004-2009 & $6-57$ & & $(9,10)$ & \\
\hline Burkina Faso & 2004-2009 & $26-187$ & & $(11,12)$ & \\
\hline Burundi & 1980-1999 & & & (9) & \\
\hline Cameroon & & $1-224$ & & (13) & \\
\hline Chad & 2004-2009 & & & (12) & \\
\hline Cote de Ivoire & & $9.6-15.9$ & & (12) & \\
\hline Ethiopia & 1990 & $0-104$ & $\mathrm{~A}$ & (14) & \\
\hline Gana & 2004-2009 & $4-165$ & & (9) & \\
\hline Gambia & 1980-1999 & $0-108$ & & (10) & \\
\hline Gana & $2004-2009$ & $0-17$ & & $(9,14)$ & \\
\hline Guinea & & 267 & & $(9,15)$ & \\
\hline Kenia & $1980-1999$ & $0-104$ & & $(12)$ & \\
\hline Mali & 1980-1999 & 158 & & $(9)$ & \\
\hline Mauritania & & $33-19.4$ & & (16) & \\
\hline Nigeria & 1983 & $0.7-52.6$ & & $(12)$ & \\
\hline Rwanda & & $0-28$ & & (9) & \\
\hline Senegal & 1980-1999 & $0-53$ Incidence $>50$ in & & (9) & \\
\hline Tanzania & & & & (17) & \\
\hline Tanzania & 2004-2009 & $0-19$ & & $(12)$ & \\
\hline Sudan & 2008 & $0-18$ & $* \mathrm{~A}$ & (14) & $\begin{array}{c}\text { Despite lack of data Sudan is included in this table } \\
\text { due to its location in the meningitis belt }\end{array}$ \\
\hline Saudi Arabia & 2000 & & A, W-135 & (12) & $\begin{array}{l}225 \text { cases in month after } 2000 \text { Hajj season.Data } \\
\text { from Saudi Arabia mostly includes cases from the } \\
\text { Hajj season }\end{array}$ \\
\hline Uruguaj & & 30 (pre-vaccine) & $\mathrm{B}$ & (18) & $\begin{array}{c}\text { Vaccine comprising serogroup C capsular } \\
\text { polysaccharide and the outer membrane vesicles } \\
\text { of serogrup meningococcus }\end{array}$ \\
\hline New Zealand & $1991-2000$ & 17.4 (pre-vaccine) & & (20) & $\begin{array}{l}\text { An OMV vaccine for Serogroup 2.6(post } \\
\text { vaccine)B was introduced in } 2004\end{array}$ \\
\hline Mongolia & 1994-1995 & $80-90$ & A & (21) & \\
\hline
\end{tabular}

Serogroup $\mathrm{X}$, formerly an unusual reason of sporadic meningitis, has been accountable for eruptions among 2006 and 2010 in Kenya, Niger, Togo, Uganda, and Burkina Faso, the final with as a minimum of 1,300 cases of serogroup $\mathrm{X}$ meningitis between the 6,732 accounted annual cases [45].

Fifteen countries from this area are classified as restrained endemicity and 18 as low. Current epidemiological supervision points out an boost of serogroup Y IMD in some divisions of Europe, which is currently the third most ordinary serogroup after B and C [23].

Uruguay stays the only nation from this area to have practiced high rates of IMD in the past 20 years. In 2001, it experienced a peak occurrence rate of meningococcal illness because of serogroup $\mathrm{B}$ and this prompted the foreword of the Cuban external membrane vesicle (OMV) B vaccine with superior exposure and a quick rejection in occurrence in following years.

Brazil and Cuba have practiced restrained occurrence rates, but have furthermore seen important advantage from the preface of meningococcal vaccines in their residents [29]. Argentina, Canada, Chile, Columbia, Mexico, the United States have performed low periods of IMD in the timeframe explained by this assessment. Serogroup Y appeared in Colombia and Venezuala, where it became the common disease-causing serogroup in 2006 [19].

The US has a general meningococcal vaccine and Canada also suggests a vaccination dosage in this age cluster continuing primary immunization at 12 months of age. Other states in this area do not have sufficient data to permit population-based estimates of their factual incidence. 


\section{International Journal of Science and Research (IJSR) \\ ISSN (Online): 2319-7064 \\ Index Copernicus Value (2013): 6.14 | Impact Factor (2014): 5.611}

South-East Asia Region Korea and Thailand are the only nations from these areas with available population-based approximations, which reveal low common rates. India has practiced recurring serogroup A outbreaks, the most current in 2005, but facts are frequently accessible only from great city centers [46]. Periodic and partial statistics from India, Bangladesh, Indonesia, Nepal, and Pakistan exclude their taxonomy, and no information is obtainable from Sri Lanka [36].

New Zealand and Mongolia have confirmed high IMD prevalence. New Zealand practiced an outburst of serogroup $B$ illness until a violent movement with the OMV vaccine was started in 2004 that has supplied partly to lowering the occurrence. Mongolia practiced serogroup A epidemics in the near the beginning 1990s.

Australia at present presents mainly serogroup B illness with moderate assault rates following the foreword of a serogroup $\mathrm{C}$ vaccine saw a noticeable rejection in rates of illness caused by the C serogroup. China, Japan, Korea, Philippines, Singapore, Taiwan, and Thailand all present low stages of IMD.

Other nations in this area do not have sufficient populationbased information to permit assessment of their accurate incidence rates. In a lot of states with epidemiological figures, mainly in Europe and North America, the age allocation of meningococcal illness shows two peaks $[6,47-$ 49]

The utmost occurrence is in babies less than one year of age, and a minor increase in incidence arises in adolescents and young adults. In one survey in the meningitis belt, the age-occurrence did not upland until the late 20 s.

The extensive and fast application of efficient antibiotics has supplied to overthrow the case casualty rate of IMD among 10 and 20 percent, but it is usually advanced in developing countries where admittance to higher stages of concern may be interrupted [52]. Despite advances in resuscitative systems, surgical interference, and significant care, there is a relentless mortality in the early hours of septicemia thanks to the quick succession of illness.

\section{Conclusion}

IMD is a stern disease that can be quickly progressive with ensuing noteworthy morbidity and mortality. Vaccines are accessible for the mainstream of sero-groups that cause illness and have established effective in tumbling the illness occurrence in nations that have used them at the population level. Management of the universal collision of these vaccines needs having them made accessible in areas that have the highest illness incidence.

This appraisal used accessible data to describe the load of meningococcal illness in dissimilar countries. Nations were categorized based on the illness endemicity, and accessible records on the most widespread serogroups were appraised to allow evidence-based choices on meningococcal vaccine application. These records assisted to notify SAGE's new suggestions on the exercise of meningococcal vaccines.
Restrictions of the assessment comprise elimination of surveys that were not available in English and the lack of a marker of the worth of examination accustomed to derive occurrence rates. It is essential that suitable surveillance developing new molecular epidemiology instruments is executed to acquire epidemiological facts on the load of meningococcal infection in states where these are not recognized. With the certification of a new affordable conjugated vaccine beside serogroup A (certified in Africa) and more lately, a multi factor serogroup $B$ vaccine in Europe inspection will be obligatory to observe the collision of these vaccines throughout straight immunity and direct protection and permit for optimization of vaccination timetables.

\section{References}

[1] Rouphael NG, Stephens DS: Neisseria meningitidis: biology, microbiology, and epidemiology. Methods Mol Biol 2012, 799:1-20.

[2] Epidemics of meningococcal disease. African meningitis belt, 2001. Wkly Epidemiol Rec 2001, 76:282-288.

[3] Edmond K, Clark A, Korczak VS, Sanderson C, Griffiths UK, Rudan I: Global and regional risk of disabling sequelae from bacterial meningitis: a systematic review and meta-analysis. Lancet Infect Dis 2010, 10:317-328.

[4] Greenwood BM: The epidemiology of acute bacterial meningitis in tropical Africa. In: Williams JD, Burnie J, editors. Bacterial meningitis. London: Academic Press; 1987. p. 61-91

[5] Lapeyssonnie L: [Cerebrospinal Meningitis in Africa]. Bull World Health Organ 1963, 28 Suppl:1-114.

[6] Harrison LH, Pelton SI, Wilder-Smith A, Holst J, Safadi MA, Vazquez JA, Taha MK, LaForce FM, von Gottberg A, Borrow R, Plotkin SA: The Global Meningococcal Initiative: recommendations for reducing the global burden of meningococcal disease. Vaccine 2011, 29:3363-3371.

[7] Meningococcal Vaccines: WHO position paper, November 2011. Weekly Epidemiological Record 2011:521-540.

[8] Gaspar M, Leite F, Brumana L, Felix B, Stella AA: Epidemiology of meningococcal meningitis in Angola, 1994-2000. Epidemiol Infect 2001, 127:421-424.

[9] Molesworth AM, Thomson MC, Connor SJ, Cresswell MP, Morse AP, Shears P, Hart CA, Cuevas LE: Where is the meningitis belt? Defining an area at risk of epidemic meningitis in Africa. Trans R Soc Trop Med Hyg 2002, 96:242-249.

[10]Epidemics of Meningococcal Disease, African Meningitis Belt, 2001. Wkly Epidemiol Rec 2001, 76:281-288.

[11] Raghunathan PL, Jones JD, Tiendrebeogo SR, Sanou I, Sangare L, Kouanda S, Dabal M, Lingani C, Elie CM, Johnson S, et al.: Predictors of immunity after a major serogroup W-135 meningococcal disease epidemic, Burkina Faso, 2002. J Infect Dis 2006, 193:607-616.

[12] WHO: Meningitis season 2007-2008: moderate levels of meningitis activity. In Global Alert and ResponseDisease Outbreak News: Wold Health Organisation, Geneva; 2008. 


\section{International Journal of Science and Research (IJSR) \\ ISSN (Online): 2319-7064}

Index Copernicus Value (2013): 6.14 | Impact Factor (2014): 5.611

[13]2001 - Meningococcal disease in the African Meningitis Belt - Update 3. In Global Alert and Response-Disease Outbreak News: World Health Organisation, Geneva; 2001.

[14] Meningococcal disease in the African Meningitis Belt, epidemic season 2006. In Global Alert and ResponseDisease Outbreak News: World Health Organisation; 2006.

[15] Expanded Program on Immunization (EPI) Wkly Epidemiol Rec 1997, 72:109-116.

[16] Epidemic meningococcal disease--Kenya and Tanzania: recommendations for travelers, 1990. MMWR Morb Mortal Wkly Rep 1990, 39:13-14.

[17] Boisier P, Nicolas P, Djibo S, Taha MK, Jeanne I, Mainassara HB, Tenebray B, Kairo KK, Giorgini D, Chanteau S: Meningococcal meningitis: unprecedented incidence of serogroup X-related cases in 2006 in Niger. Clin Infect Dis 2007, 44:657-663.

[18] WHO: Meningococcal disease in Saudi Arabia and the Netherlands - Update. In Global Alert and ResponseDisease Outbreak News: World Health Organisation; 2000.

[19] Safadi MA, Cintra OA: Epidemiology of meningococcal disease in Latin America: current situation and opportunities for prevention. Neurol Res 2010, 32:263-271.

[20] Baker MG, Martin DR, Kieft CE, Lennon D: A 10-year serogroup B meningococcal disease epidemic in New Zealand: descriptive epidemiology, 1991-2000. J Paediatr Child Health 2001, 37:S13-19.

[21] Mendsaikhan J, Watt JP, Mansoor O, Suvdmaa N, Edmond K, Litt DJ, Nymadawa P, Baoping Y, Altantsetseg D, Slack M: Childhood bacterial meningitis in Ulaanbaatar, Mongolia, 2002-2004. Clin Infect Dis 2009, 48 Suppl 2:S141-S146.

[22] von Gottberg A, du Plessis M, Cohen C, Prentice E, Schrag S, de Gouveia L, Coulson G, de Jong G, Klugman K: Emergence of endemic serogroup W135 meningococcal disease associated with a high mortality rate in South Africa. Clin Infect Dis 2008, 46:377-386.

[23] Annual Epidemiological Report 2012. Reporting on 2010 surveillance data and 2011 epidemic intelligence data. Stockholm: European Centre for Disease Prevention and Control.; 2013.

[24] Trotter CL, Chandra M, Cano R, Larrauri A, Ramsay ME, Brehony C, Jolley KA, Maiden MC, Heuberger S, Frosch M: A surveillance network for meningococcal disease in Europe. FEMS Microbiol Rev 2007, 31:2736.

[25] Kafetzis DA, Stamboulidis KN, Tzanakaki G, Kourea Kremastinou J, Skevaki CL, Konstantopoulos A, Tsolia $\mathrm{M}$ : Meningococcal group $\mathrm{C}$ disease in Greece during 1993-2006: the impact of an unofficial single-dose vaccination scheme adopted by most paediatricians. Clin Microbiol Infect 2007, 13:550-552.

[26] Muscat M, Spiteri G, Calleja N, Haider J, Gray SJ, Melillo JM, Mamo J, Cuschieri P: Invasive meningococcal disease in Malta: an epidemiological overview, 1994-2007. J Med Microbiol 2009, 58:14921498.

[27] Iversen BG, Aavitsland P: Meningococcal disease in Norway 1992-1995. Epidemiology and fatality. Scand J Infect Dis 1996, 28:253-259.
[28] Meningococcal

[http://ec.europa.eu/health/ph information/ dissemination/echi/docs/meningoccocal_en.pdf]

[29]Dickinson FO, Perez AE: Bacterial meningitis in children and adolescents: an observational study based on the national surveillance system. BMC Infect Dis 2005, 5:103.

[30] Guidelines for the early clinical and public health management of meningococcal disease in Australia. Revised Edition 2007. Communicable Diseases Network Australia: Commonwealth Department of Health and Ageing; 2007.

[31] Efron AM, Sorhouet C, Salcedo C, Abad R, Regueira M, Vazquez JA: W135 invasive meningococcal strains spreading in South America: significant increase in incidence rate in Argentina. J Clin Microbiol 2009, 47:1979-1980.

[32] Whalen CM, Hockin JC, Ryan A, Ashton F: The changing epidemiology of invasive meningococcal disease in Canada, 1985 through 1992. Emergence of a virulent clone of Neisseria meningitidis. JAMA 1995, 273:390-394.

[33] Bettinger JA, Scheifele DW, Le Saux N, Halperin SA, Vaudry W, Tsang R: The impact of childhood meningococcal serogroup $\mathrm{C}$ conjugate vaccine programs in Canada. Pediatr Infect Dis J 2009, 28:220 224.

[34] MacLennan J, Kafatos G, Neal K, Andrews N, Cameron JC, Roberts R, Evans MR, Cann K, Baxter DN, Maiden MC, Stuart JM: Social behavior and meningococcal carriage in British teenagers. Emerg Infect Dis 2006, 12:950-957.

[35]Bae SM, Kang YH: Serological and genetic characterization of meningococcal isolates in Korea. Jpn J Infect Dis 2008, 61:434-437.

[36] Vyse A, Wolter JM, Chen J, Ng T, Soriano-Gabarro M: Meningococcal disease in Asia: an under-recognized public health burden. Epidemiol Infect 2011:1-19.

[37] Hu X: [Surveillance of epidemiological features for epidemic cerebrospinal meningitis in China during 1980s]. Zhonghua Liu Xing Bing Xue Za Zhi 1990, 11:321-324.

[38] Shao Z, Li W, Ren J, Liang X, Xu L, Diao B, Li M, Lu $M$, Ren $H$, Cui $Z$, et al.: Identification of a new Neisseria meningitidis serogroup $\mathrm{C}$ clone from Anhui province, China. Lancet 2006, 367:419-423.

[39] Infectious Agents Surveillance Report. Meningococcal meningitis, 1999- 2004, Japan. http://idsc.nih.go.jp/iasr/26/300/tpc300.html. (Report IAS ed., vol. 26. pp. 33-34; 2005:33-34.

[40] Weekly Infectious Disease Bulletin-Ministry of Health, Singapore

Infectious_Diseases_Bulletin/2011/December/2011_we ek 49.pdf. 2011.

[41] Wilder-Smith A, Goh KT, Barkham T, Paton NI: Hajjassociated outbreak strain of Neisseria meningitidis serogroup W135: estimates of the attack rate in a defined population and the risk of invasive disease developing in carriers. Clin Infect Dis 2003, 36:679-

[42] Wang JL, Liu DP, Yen JJ, Yu CJ, Liu HC, Lin CY, Chang SC: Clinical features and outcome of sporadic serogroup W135 disease Taiwan. BMC Infect Dis 2006, 6:7. 


\section{International Journal of Science and Research (IJSR) \\ ISSN (Online): 2319-7064}

Index Copernicus Value (2013): 6.14 | Impact Factor (2014): 5.611

[43] Greenwood BM, Blakebrough IS, Bradley AK, Wali S, Whittle HC: Meningococcal disease and season in subSaharan Africa. Lancet 1984, 1:1339-1342.

[44] Bishai DM, Champion C, Steele ME, Thompson L: Product development partnerships hit their stride: lessons from developing a meningitis vaccine for Africa. Health Aff (Millwood) 2011, 30:1058-1064.

[45] Xie O, Pollard AJ, Mueller JE, Norheim G: Emergence of serogroup X meningococcal disease in Africa: need for a vaccine. Vaccine 2013, 31:2852-2861.

[46] Sinclair D, Preziosi MP, Jacob John T, Greenwood B: The epidemiology of meningococcal disease in India. Trop Med Int Health 2010, 15:1421-1435.

[47]Dell E, Bedford D, McMahon B, Nicholson A: Meningococcal disease--management of serogroup $\mathrm{C}$ clusters in a hyperendemic area. Ir Med J 2001, 94:166, $168-169$.

[48] Annual report of the Australian Meningococcal Surveillance Programme, 2009. Commun Dis Intell 2010, 34:291-302.

[49] Prevention and control of meningococcal disease: recommendations for use of meningococcal vaccines in pediatric patients. Pediatrics 2005,116:496-505.

[50] Campagne G, Schuchat A, Djibo S, Ousseini A, Cisse L, Chippaux JP:Epidemiology of bacterial meningitis in Niamey, Niger, 1981-96. Bull World Health Organ 1999, 77:499-508.

[51] Peltola H, Kataja JM, Makela PH: Shift in the agedistribution of meningococcal disease as predictor of an epidemic? Lancet 1982, 2:595-597.

[52] Cartwright K, Noah N, Peltola H: Meningococcal disease in Europe: epidemiology, mortality, and prevention with conjugate vaccines. Report of a European advisory board meeting Vienna, Austria, 6-8 October, 2000. Vaccine 2001, 19:4347-4356. 